\title{
Meningkatkan Hasil Belajar Siswa Dalam Reading: Memahami Makna Teks Tulis Fungsional Dan Esai Pendek Sederhana Berbentuk Narrative Dan Report Melalui Metode Snowball Drilling Di Kelas IX-B SMPN 2 Pahae Jae T.P 2016/2017
}

\author{
Darmauli Gultom \\ Smp Negeri 2 Pahae Jae
}

\begin{abstract}
Abstrak
Metode Snowball Drilling adalah metode pembelajaran yang dilakukan guru dengan memberikan bentuk latihan yang dituliskan di dalam selembar kertas dan kemudian kertas tersebut dibentuk menjadi bola- bola salju yang akan dilemparkan atau digelindingkan kepada setiap siswa. Penelitian ini bertujuan untuk mengetahui adanya peningkatan hasil belajar Bahasa Inggris siswa SMPN 2 Pahae Jae Kelas IX-b dalam Reading: Memahami Makna Teks Tulis Fungsional Dan Esei Pendek Sederhana Berbentuk Narrative dan report melalui Metode Snowball Drilling T.P 2016/2017, termasuk peningkatan aktivitas dan respon belajar siswa terhadap mata pelajaran Bahasa Inggris. Jenis Penelitian yang dilakukan adalah penelitian tindakan kelas yang dilaksanakan dalam 2 siklus. Tiap siklus terdiri dari 4 tahap, yaitu perencanaan, pelaksanaan tindakan, observasi, analisis dan refleksi. Penelitian ini dilaksanakan di SMPN 2 Pahae Jae kabupaten Tapanuli Utara dengan subjek penelitian siswa Kelas IX-b sejumlah 20 orang. Data aktifitas siswa diperoleh dari hasil observasi melalui instrumen penilaian aktifitas, data hasil belajar diperoleh dari hasil tes akhir hasil belajar setiap siklus, dan data respon belajar siswa diperoleh dari hasil tes melalui instrumen penilaian respon. Hasil penelitian menunjukkan, (1) pada siklus 1 nilai rata-rata aktifitas belajar siswa $70,5 \%$, nilai rata-rata hasil belajar siswa $66,75 \%$, dan nilai rata-rata respon belajar $72,00 \%$, (2) pada siklus 2, nilai aktifitas belajar siswa rata-rata adalah $85,75 \%$, nilai rata-rata hasil belajar 75,25 \%, dan nilai rata-rata respon belajar siswa 85,5\%. Berdasarkan nilai rata-rata hasil belajar sesuai data hasil pada siklus 1 dan siklus 2 menunjukkan bahwa terdapat peningkatan hasil belajar Bahasa Inggris siswa SMPN 2 Pahae Jae Kelas IX-b dalam Reading: Memahami Makna Teks Tulis Fungsional Dan Esei Pendek Sederhana Berbentuk Narrative dan report melalui Metode Snowball Drilling T.P 2016/2017.
\end{abstract}

Kata Kunci : Hasil Belajar, Mata Pelajaran Bahasa Inggris, Metode Snowball Drilling

\section{PENDAHULUAN}

Pendidikan pada umumnya, merupakan suatu kegiatan yang universal dalam kehidupan manusia. Dimanapun di dunia ini terdapat masyarakat dan disana pula terdapat pendidikan. Menurut Muhibinsyah dalam Sagala( 2006), pendidikan dapat diartikan sebagai sebuah proses dengan metode-metode tertentu sehingga orang memperoleh pengetahuan, pemahaman, dan cara bertingkah laku yang sesuai dengan kebutuhan. Pendidikan dapat dijadikan sebagai sarana yang tepat untuk menghadapi masa depan serta merupakan salah satu kebutuhan mutlak yang harus dipenuhi sepanjang hayat. Pendidikan dituntut untuk menghasilkan siswa yang berkualitas dan berwawasan internasional serta tidak hanya 
sekedar memenuhi target kurikulum saja. Untuk mewujudkan hal tersebut pendidikan harus bersifat menyeluruh, baik dari segi kompetensi kognitif, afektif, maupun psikomotor. Selain itu, pembelajaran juga harus dirancang sedemikian rupa sehingga siswa tidak cepat merasa bosan pada saat pembelajaran sedang berlangsung. Untuk itu guru harus dapat menciptakan suasana pembelajaran yang kondusif.

Pendidikan merupakan usaha yang sadar dan terencana untuk mewujudkan suasana belajar dan proses pembelajaran agar peserta didik secara aktif mengembangkan potensi dirinya untuk memiliki kekuatan spiritual keagamaan, pengendalian diri, keterampilan, kecerdasan, akhlak mulia serta keterampilan yang diperlukan dirinya, masyarakat, bangsa, dan negara. (Undang-Undang RI No. 20 Tahun 2003). Oleh karena itu pengembangan pendidikan harus dilakukan untuk meningkatkan kualitas pendidikan suatu bangsa. Kemajuan pendidikan harus dikembangkan dengan baik agar dapat meningkatkan mutu pendidikan dan juga dapat meningkatkan harkat dan martabat suatu bangsa.

Melalui pendidikan, tercipta manusia yang cerdas, trampil, berwawasan luas, disiplin beriman, bertaqwa serta bertanggung jawab didalam kehidupan. Untuk dapat mencapai tujuan pendidikan tersebut, sekolah sebagai salah satu intitusi pendidikan formal memiliki tanggung jawab yang besar untuk mewujudkannya. Upaya untuk mewujudkan itu menjadi tanggung jawab semua stakeholder pendidikan yang salah satunya adalah komponen guru sebagai ujung tombak pendidikan.

Menurut Hammalik (1994), guru bertanggung jawab melaksanakan kegiatan pendidikan di sekolah dalam arti memberikan bimbingan dan pengajaran kepada para siswa". Guru harus dapat melakukan suatu inovasi yang menyangkut tugasnya sebagai pendidik yang berkaitan dengan tugas mengajar siswa. Inovasi-inovasi yang dilakukan guru dalam tugasnya sebagai pendidik diharapkan mampu meningkatkan prestasi belajar siswa. Mengingat bahwa guru juga memberi pengaruh terhadap prestasi belajar siswa.

Persoalan penerapan strategi atau pendekatan pembelajaran menjadi salah faktor yang dapat mempengaruhi hasil belajar. Keberhasilan siswa dalam proses pembelajaran dapat dipengaruhi oleh faktor dari dalam individu maupun dari luar individu. Faktor dari dalam individu meliputi fisik dan psikis, contoh faktor psikis diantaranya adalah motivasi. Motivasi belajar siswa yang tinggi dapat menunjang keberhasilan belajar, akan tetapi motivasi belajar siswa yang rendah merupakan hambatan yang dapat berakibat pada hasil belajar rendah. Untuk itu guru harus dapat memilih strategi atau strategi yang tepat agar tercipta situasi pembelajaran yang menarik sehingga dapat menumbuhkan motivasi belajar dan keberhasilan siswa dalam belajar tercapai.

Pendekatan pembelajaran guru yang monoton adalah suatu hal yang masih banyak ditemukan di sekolah termasuk dalam pembelajaran bahasa Indonesia. Padahal pembelajaran bahasa Indonesia diantaranya bertujuan agar peserta didik memiliki kemampuan berkomunikasi secara efektif dan efisien 
dengan etika yang berlaku secara lisan maupun tulisan, sehingga bahasa Indonesia dapat digunakan dengan tepat dan kreatif. Untuk mewujudkan tujuan tersebut maka tentu diperlukan berbagai variasi pendekatan pembelajaran pembelajaran agar lebih menarik (Sumarni, 2012).

Bahasa memiliki peran sentral dalam perkembangan intelektual, sosial, dan emosional peserta didik dan merupakan penunjang keberhasilan dalam mempelajari semua bidang studi. Bahasa Inggris merupakan alat untuk berkomunikasi secara lisan dan tulis. Berkomunikasi adalah memahami dan mengungkapkan informasi, pikiran, perasaan, dan mengembangkan ilmu pengetahuan, teknologi, dan budaya. Kemampuan berkomunikasi dalam pengertian yang utuh adalah kemampuan berwacana, yakni kemampuan memahami dan/atau menghasilkan teks lisan dan/atau tulis yang direalisasikan dalam empat keterampilan berbahasa, yaitu mendengarkan ((listening), berbicara (writing), membaca (reading), dan menulis (writing). Salah satu komponen keberhasilan pendidikan adalah kurikulum dengan segala implementasinya.

Bahasa memiliki peran sentral dalam perkembangan intelektual, sosial, dan emosional peserta didik dan merupakan penunjang keberhasilan dalam mempelajari semua bidang studi. Pembelajaran bahasa diharapkan membantu peserta didik mengenal dirinya, budayanya, dan budaya orang lain. Selain itu, pembelajaran bahasa juga membantu peserta didik mampu mengemukakan gagasan dan perasaan, berpartisipasi dalam masyarakat, dan bahkan menemukan serta menggunakan kemampuan analitis dan imaginatif yang ada dalam dirinya.

Bahasa Inggris merupakan alat untuk berkomunikasi secara lisan dan tulis. Berkomunikasi adalah memahami dan mengungkapkan informasi, pikiran, perasaan, dan mengembangkan ilmu pengetahuan, teknologi, dan budaya. Kemampuan berkomunikasi dalam pengertian yang utuh adalah kemampuan berwacana, yakni kemampuan memahami dan/atau menghasilkan teks lisan dan/atau tulis yang direalisasikan dalam empat keterampilan berbahasa, yaitu mendengarkan, berbicara, membaca dan menulis. Keempat keterampilan inilah yang digunakan untuk menanggapi atau menciptakan wacana dalam kehidupan bermasyarakat. Oleh karena itu, mata pelajaran Bahasa Inggris diarahkan untuk mengembangkan keterampilan-keterampilan tersebut agar lulusan mampu berkomunikasi dan berwacana dalam bahasa Inggris pada tingkat literasi tertentu. (Permendiknas Nomor 22 Tahun 2006)

Tingkat literasi mencakup performative, functional, informational, dan epistemic.Pada tingkat performative, orang mampu membaca, menulis, mendengarkan, dan berbicara dengan simbol-simbol yang digunakan. Pada tingkat functional, orang mampu menggunakan bahasa untuk memenuhi kebutuhan hidup sehari-hari seperti membaca surat kabar, manual atau petunjuk. Pada tingkat informational, orang mampu mengakses pengetahuan dengan kemampuan berbahasa, sedangkan pada tingkat epistemic orang mampu mengungkapkan pengetahuan ke dalam bahasa sasaran (Wells,1987, dalam Permendiknas Nomor 22 Tahun 2006). 
Pembelajaran bahasa Inggris di SMP/MTs ditargetkan agar peserta didik dapat mencapai tingkat functional yakni berkomunikasi secara lisan dan tulis untuk menyelesaikan masalah sehari-hari, sedangkan untuk SMA/MA diharapkan dapat mencapai tingkat informational karena mereka disiapkan untuk melanjutkan pendidikannya ke perguruan tinggi. Tingkat literasi epistemic dianggap terlalu tinggi untuk dapat dicapai oleh peserta didik SMA/MA karena bahasa Inggris di Indonesia berfungsi sebagai bahasa asing.

Menurut kurikulum tingkat satuan pendidikan (KTSP), tujuan mempelajari bahasa Inggris SMP adalah agar peserta didik memiliki kemampuan: 1) Mengembangkan kompetensi berkomunikasi dalam bentuk lisan dan tulis untuk mencapai tingkat literasi functional, 2) Memiliki kesadaran tentang hakikat dan pentingnya bahasa Inggris untuk meningkatkan daya saing bangsa dalam masyarakat global; 3) Mengembangkan pemahaman peserta didik tentang keterkaitan antara bahasa dengan budaya.

Bahasa Inggris merupakan salah satu mata pelajaran yang kadang sulit dipahami oleh sebagian siswa di Sekolah Menengah Pertama (SMP). Hal ini dikarenakan bahasa Inggris bukan merupakan bahasa sehari-hari siswa di sekolah maupun di luar sekolah, dan sebagian siswa malas mengikuti kursus bahasa Inggris. Kenyataan di sekolah menunjukkan adanya siswa yang mengalami masalah belajar atau berkesulitan belajar bahasa Inggris. Hal ini ditandai dengan rendahnya hasil belajar siswa, baik berdasarkan hasil ulangan harian maupun ujian semester. Data nilai rata-rata ujian akhir semester ganjil bahasa Inggris siswa SMPN 2 Pahae Jae kelas IX-b pada semester ganjil T.P 2016/2017 adalah 60,00 . Hasil ini menunjukkan bahwa secara rata-rata masih belum memenuhi kriteria ketuntasan yaitu $75 \%$. Selain itu, berdasarkan penilaian peneliti terhadap aspek membaca (reading) siswa, $50 \%$ diantaranya masih mengalami kesulitan dalam membaca seperti mengungkapkan makna gagasan dalam teks tulis fungsional pendek sangat sederhana dengan menggunakan ragam bahasa tulis secara akurat, lancar dan berterima untuk berinteraksi dengan lingkungan terdekat. Siswa kelas IX-b merupakan siswa yang paling banyak teridentifikasi mengalami kesulitan membaca teks bahasa Inggris. Jumlah siswa kelas IX-b SMPN 2 Pahae Jae sebanyak 20 orang, sementara yang teridentifikasi mengalami kesulitan membaca sebanyak 6-8 orang.

Dalam upaya mengatasi kesulitan belajar siswa dalam pelajaran bahasa Inggris, maka penerapan strategi pembelajaran yang bervariasi menjadi salah satu upaya guru yang perlu dilakukan secara terencana dan bertujuan. Hal ini sesuai pendapat Kartadinata (2009) bahwa "siswa yang mengalami masalah belajar perlu mendapatkan bantuan agar masalahnya tidak berlarut-larut yang nantinya dapat mempengaruhi proses perkembangan siswa".

Sudah menjadi tugas dan tanggung jawab guru dalam memberikan penanganan atau bimbingan terhadap siswa yang berkesulitan belajar. Sehubungan dengan tugas guru tersebut, maka guru harus memiliki kompetensi melaksanakan pengajaran secara efektif dan efisien, di antaranya dalam 
penerapan berbagai strategi pembelajaran. Penerapan strategi pembelajaran yang variatif akan dapat meningkatkan tingkat penguasaan siswa terhadap materi yang dipelajari seperti dalam pelajaran bahasa Inggris.

Salah satu strategi pembelajaran yang dapat diterapkan adalah metode Snowball Drilling. Metode ini dilakukan dalam proses pembelajaran bertujuan untuk menguatkan pengetahuan yang diperoleh siswa dari membaca bahan- bahan bacaan sebelumnya.Metode Snowball Drilling ini memenuhi beberapa kriteria pembelajaran yang aktif, efektif, efisien, dan bermutu karena dalam proses pembelajarannya menuntut kreatifitas dan efektivitas berfikir siswa sehingga dapat meningkatkan daya serap siswa dalam mempelajari. Dengan menerapkan Metode Snowball Drilling dalam pembelajaran bahasa Inggris diharapkan dapat lebih menumbuhkan suasana pembelajaran yang menyenangkan sehingga siswa akan berminat dan termotivasi dalam belajar yang pada akhirnya dapat meningkatkan hasil belajar.

\section{METODOLOGI PENELITIAN}

Penelitian ini merupakan penelitian tindakan kelas (PTK) yang dilaksanakan terdiri dari 2 siklus dan tiap siklusnya terdiri dari 2 kali kegiatan tatap muka , dengan masing - masing tatap muka selama 2 jam pelajaran (2x40 menit). Setiap siklus terdiri dari 4 tahap, yaitu perencanaan, pelaksanaan, pengamatan, dan refleksi. Penelitian tindakan kelas ini dilaksanakan di SMPN 2 Pahae Jae terhadap siswa kelas IX-b mulai tanggal 23 Januari s.d 04 Maret 2017. Pelaksanaan penelitian dilakukan sesuai dengan jadwal pembelajaran harian di SMPN 2 Pahae Jae T.P 2016/2017 semester genap. Pengumpulan data dilakukan dengan teknik observasi, tes dan angket. Analisis data menggunakan Metode Snowball Drilling pada materi "'reading: Memahami makna teks tulis fungsional dan esei pendek sederhana berbentuk narrative dan report'", diolah dan dianalisis secara kualitatif dengan mengacu pada model analisis interaktif yaitu interaksi dari ketiga komponen utama. Tiga komponen utama tersebut menurut Miles dan Huberman (1992), yaitu "reduksi data, paparan data, dan penarikan kesimpulan". Berdasarkan data yang telah terkumpul, maka dilakukan analisis dan refleksi terhadap hasil dan proses tindakan yang telah dilakukan. Analisis tersebut dilakukan dengan cara membandingkan hasil tindakan dengan indikator kinerja yang diterapkan. Jika hasil tindakan lebih baik atau sama dengan indikator yang telah diterapkan, maka penelitian tindakan kelas ini dinilai berhasil. Jika hasilnya lebih rendah atau lebih jelek, maka penelitian tindakan ini ditetapkan belum berhasil, dan selanjutnya dilakukan perbaikan ulang dalam siklus kegiatan kedua dan seterusnya sampai tindakan berhasil.

\section{HASIL PENELITIAN DAN PEMBAHASAN}

Sesuai dengan pelaksanaan penelitian tindakan kelas siklus I dan siklus II maka diperoleh data sebagai berikut : 
1. Data peningkatan aktivitas belajar siswa terhadap mata pelajaran bahasa Inggris pada siklus I dan siklus II.

Tabel 4. 7 Persentase peningkatan aktivitas belajar siswa terhadap mata pelajaran bahasa Inggris pada siklus I dan siklus ||

\begin{tabular}{|l|l|l|l|l|l|}
\hline \multirow{3}{*}{ Data Yang Diperoleh } & \multicolumn{2}{|l|}{ Hasil } & \multirow{2}{*}{$\begin{array}{c}\text { Peningkatan } \\
\text { rata-rata }\end{array}$} \\
\cline { 2 - 5 } & \multicolumn{2}{|c|}{ Siklus I } & \multicolumn{2}{|c|}{ Siklus II } & \\
\cline { 2 - 5 } & Frek & $\%$ & Frek & $\%$ & $13,5 \%$ \\
\hline$\sum$ Siswa Yang Tuntas & 16 & 20 & 18 & 90 & $13,5 \%$ \\
\hline
\end{tabular}

Indikator $\geq 85 \%$
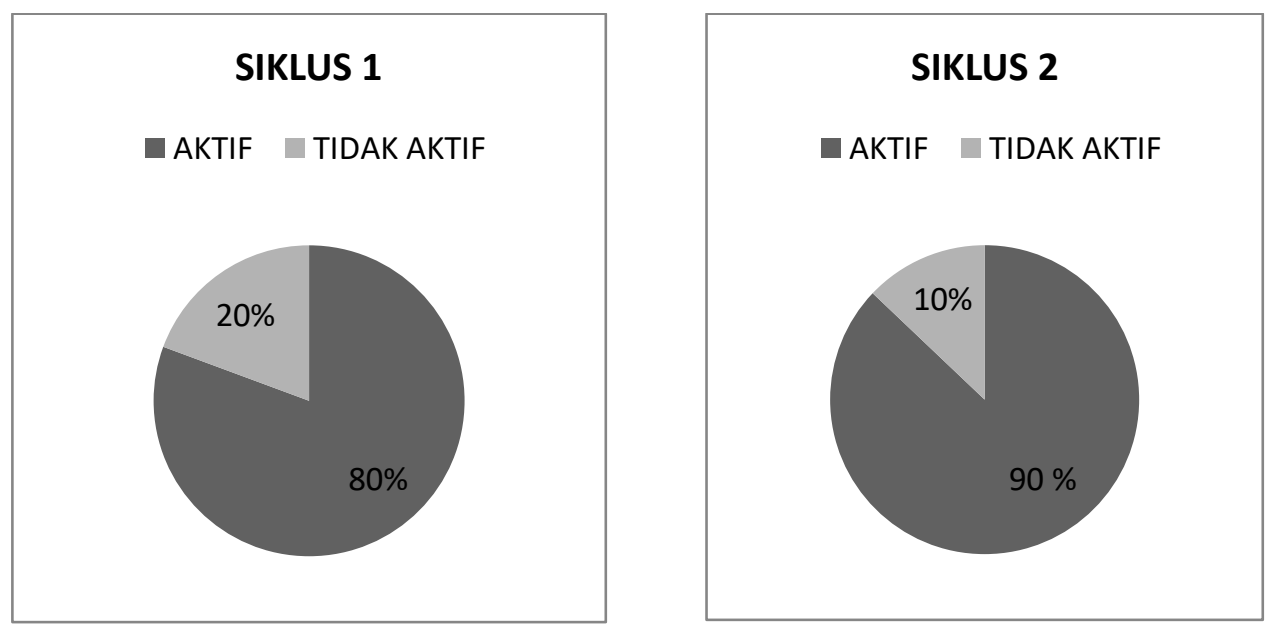

Grafik 1. 1. Grafik peningkatan aktifitas belajar bahasa Inggris siklus 1 dan siklus 2

Dari tabel 4.7 dan grafik 1.1 di atas dapat dilihat secara jelas bahwa aktivitas siswa dengan menggunakan pembelajaran Metode Snowball Drilling learning dari siklus I sampai siklus II mengalami peningkatan yaitu sebesar 13,5 \%. Hal ini disebabkan dengan Metode Snowball Drilling learning siswa lebih memberi kesempatan siswa untuk aktif berdiskusi dan bekerjasama dalam kelompok.

2. Data peningkatan hasil belajar siswa terhadap mata pelajaran bahasa Inggris pada siklus I dan siklus II.

Tabel 4. 8 Persentase peningkatan hasil belajar bahasa Inggris pada siklus I dan siklus II

\begin{tabular}{|l|l|l|l|l|l|}
\hline \multirow{2}{*}{ Data Yang Diperoleh } & \multicolumn{2}{|l|}{ Hasil } & \multirow{2}{*}{$\begin{array}{c}\text { Peningkatan } \\
\text { rata-rata }\end{array}$} \\
\cline { 2 - 5 } & \multicolumn{2}{|c|}{ Siklus I } & \multicolumn{2}{|c|}{ Siklus II } & \\
\cline { 2 - 5 } & Frek & $\%$ & Frek & $\%$ & \\
\hline$\sum$ Siswa Yang Tuntas & 15 & 75 & 18 & 90 & $8,5 \%$ \\
\hline
\end{tabular}


Indikator $\geq 75 \%$
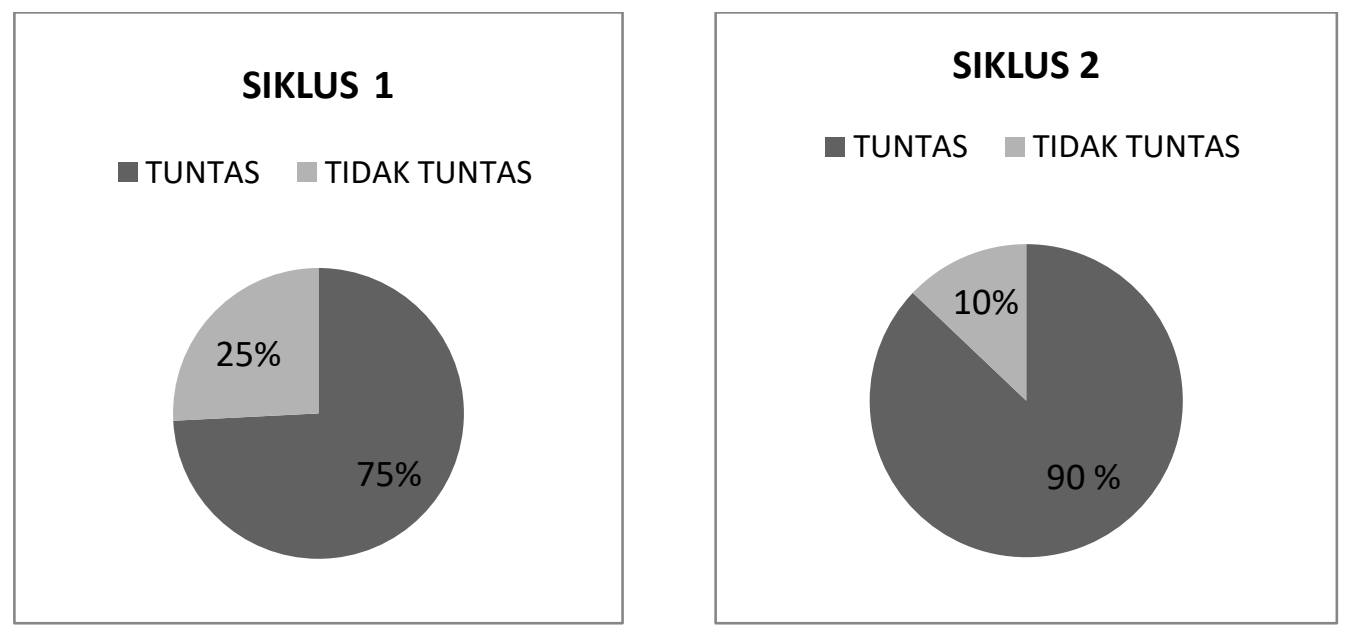

Dari tabel 4.8 dan grafik 1.2 diatas dapat dilihat secara jelas bahwa hasil belajar bahasa Inggris siswa SMPN 2 Pahae Jae kelas IX-b dengan menggunakan Metode Snowball Drilling learning dari siklus | sampai siklus || mengalami peningkatan sebesar 8,5\%. Pada siklus 2, jumlah siswa yang memperoleh nilai KKM ( $\geq 65 \%)$ mencapai 18 siswa atau $90 \%$.

Peningkatan ini dipengaruhi oleh faktor dimana kegiatan pembelajaran dengan Metode Snowball Drilling learning dapat merangsang siswa belajar dan mempercepat daya tangkap otak siswa dalam belajar karena pembelajaran dikemas lebih menarik dan menyenangkan sehingga hasil belajar siswa meningkat.

1. Data peningkatan respon belajar siswa terhadap mata pelajaran bahasa Inggris pada siklus I dan siklus II.

Tabel 4. 9 Persentase peningkatan respon belajar siswa terhadap mata pelajaran bahasa Inggris pada siklus I dan siklus ||

\begin{tabular}{|c|c|c|c|c|c|}
\hline \multirow{2}{*}{ Data Yang Diperoleh } & \multicolumn{4}{|c|}{ Hasil } & \multirow{2}{*}{ Peningkatan } \\
\cline { 2 - 5 } & \multicolumn{2}{|c|}{ Siklus I } & \multicolumn{2}{|c|}{ Siklus II } & \\
\cline { 2 - 5 } & Frek & $\%$ & Frek & $\%$ & \\
\hline $\begin{array}{l}\text { } \\
\text { Respon piswa Yang Memberi }\end{array}$ & 17 & 85 & 18 & 90 & $13,5 \%$ \\
\hline
\end{tabular}



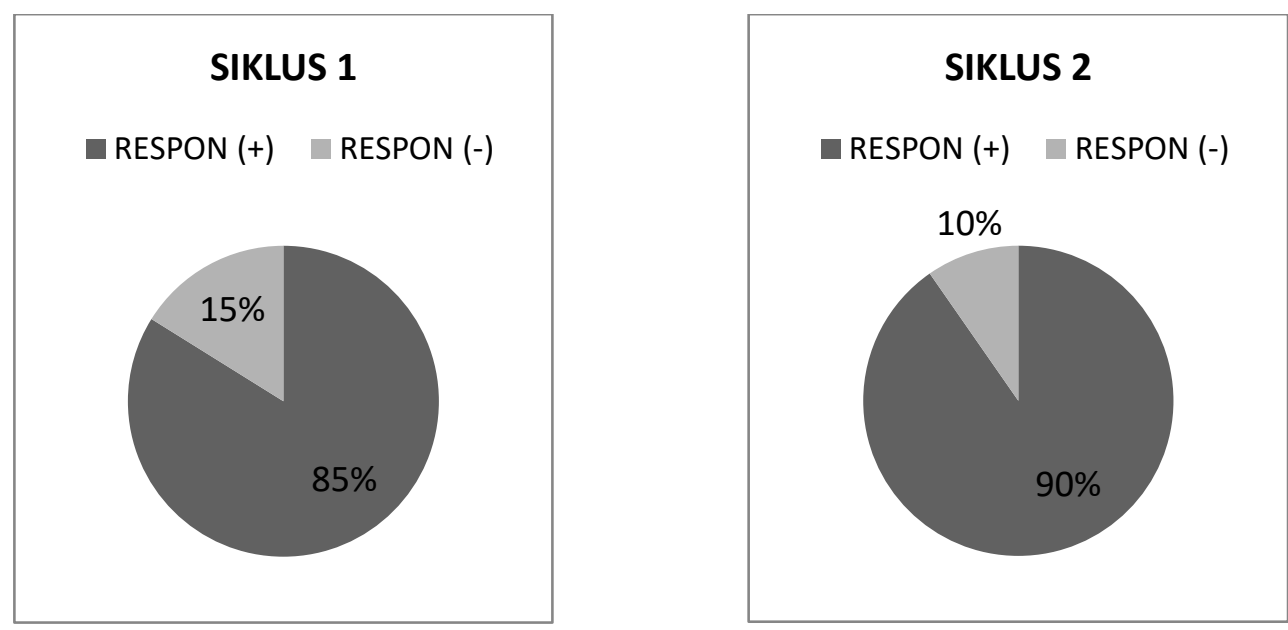

Grafik 1. 3. Grafik peningkatan respon belajar bahasa Inggris siklus 1 dan siklus 2

Dari tabel 4.9 dan grafik 1.3 di atas menunjukan bahwa respon belajar bahasa Inggris dengan menggunakan Metode Snowball Drilling learning dari siklus I sampai siklus II mengalami peningkatan sebesar $13,5 \%$. Hal ini disebabkan dengan Metode Snowball Drilling learning siswa lebih senang dalam belajar dan siswa juga merasa pembelajaran Metode Snowball Drilling learning merupakan hal yang baru bagi mereka.

Dari pembahasan hasil penelitian selama siklus I dan siklus II nampak bahwa hasil belajar, aktivitas siswa maupun respon siswa pada pembelajaran bahasa Inggris materi "'reading: memahami makna teks tulis fungsional dan esei pendek sederhana berbentuk narrative dan report" dengan Metode Snowball Drilling learning mengalami peningkatan yang cukup signifikan. Dengan demikian hipotesis penelitian ini yang mengatakan bahwa "Penerapan Metode Snowball Drilling learning dapat meningkatkan hasil belajar bahasa Inggris siswa SMPN 2 Pahae Jae kelas IX-b pada materi "'reading: memahami makna teks tulis fungsional dan esei pendek sederhana berbentuk narrative dan report"' dapat diterima.

\section{KESIMPULAN}

Berdasarkan hasil pembahasan yang telah dilakukan maka dapat disimpulkan bahwa :

1. Terdapat peningkatan aktivitas belajar bahasa Inggris siswa SMPN 2 Pahae Jae kelas IX-b pada materi "'reading: Memahami makna teks tulis fungsional dan esei pendek sederhana berbentuk narrative dan report” melalui Metode Snowball Drilling T.P 2016/2017. 
Meningkatkan Hasil Belajar Siswa Dalam Reading: Memahami Makna Teks Tulis Fungsional Dan Esai Pendek Sederhana

Berbentuk Narrative Dan Report Melalui Metode Snowball Drilling Di Kelas IX-B SMPN 2 Pahae Jae T.P 2016/2017

2. Terdapat peningkatan hasil belajar bahasa Inggris siswa SMPN 2 Pahae Jae kelas IX-b pada materi "'reading: Memahami makna teks tulis fungsional dan esei pendek sederhana berbentuk narrative dan report" melalui Metode Snowball Drilling T.P 2016/2017.

3. Terdapat peningkatan respon belajar bahasa Inggris siswa SMPN 2 Pahae Jae kelas IX-b pada materi "'reading: Memahami makna teks tulis fungsional dan esei pendek sederhana berbentuk narrative dan report" melalui Metode Snowball Drilling T.P 2016/2017.

\section{DAFTAR PUSTAKA}

Arikunto, S. 2008. Penelitian Tindakan Kelas. Jakarta . PT. Bumi Aksara.

Brewster, J., at al. (2002). The Primary English Teacher Guide New Edition. England: Pearson Education Limited in Association with Penguin Books Ltd.

Daryanto. 2007. Evaluasi pendidikan. Jakarta. Rineka Cipta.

Depdiknas, 2007. Standar Isi. Jakarta. Depdiknas.

De Porter, B. 2003. Quantum Teaching, Terjemahan oleh Ary Nilandari Cet. XI. Bandung

Djamarah, S. B. 2002. Strategi Belajar Mengajar. Jakarta. Rineka Cipta.

Dimyati dan Mudjiono. 1999. Belajar Mengajar. Jakarta. Rineka Cipta.

Farida, R. 2006. Pengajaran Membaca Di Tingkat Dasar. Jakarta. Bumi Aksara.

Hamalik, O. 2003. Kurikulum dan Pembelajaran. Jakarta. Bumi Aksara.

Kartadinata, S. 1998. Bimbingan di Sekolah. Jakarta: Depdikbud

Miles, M. B \& Huberman, A. M. 1992. Analisis Data Kualitatif. Terjemahan. Tjejep Rohendi. Jakarta. UI Perss

Muhibbin, S. 2004. Psikologi Pendidikan dengan Pendekatan Baru. Bandung. PT. Remaja Rosdakarya.

Mulyana, E. 2005. Menjadi Guru Profesional. Bandung: Remaja Rosdakarya.

Mulyono, A. 1999. Pendidikan Bagi Anak Berkesulitan Belajar. Jakarta. Rineka Cipta.

Nur, M. 1996. Konsep Tentang Arah Pengembangan Pendidikan SMP dan SMU Lima Tahun yang Akan

Datang. Jakarta: Depdikbud Direktorat Jenderal Pendidikan Dasar dan Menengah Umum

Orr, J.K. 1999. Growing Up with English. America. United State Departement of State Washington, DC.

Permendiknas, No 20 tahun 2007. Standar Penilaian Pendidikan. Jakarta. Depdiknas

Pringgodigdo, A. G, dkk. 1993. Ensiklopedi Umum, Yogyakarta. Yayasan Kanisuius

Purwanto, N. 2006. Prinsip-Prinsip dan Teknik Evaluasi Pengajaran. Bandung. PT Remaja Rosdakarya.

Resmini, N. dkk. 2006. Pembinaan dan Pengembangan Pembelajaran Bahasa dan Sastra Indonesia.

Bandung: UPI Press.

Riyanto, Theo. 2002. Pembelajaran sebagai Proses Bimbingan Pribadi. Jakarta. Grasindo.

Rohani, A. 1991. Pengelolaan Pengajaran. Jakarta. Rineka Cipta. 
Sagala, S. 2006. Konsep dan Makna Pembelajaran. Bandung. Alfabeta.

Siberman, M. 2001. Active Learning 101 Strategi Pembelajaran Aktif. Yogyakarta. Yappendis.

Sriyono, dkk. 1992. Teknik Belajar Mengajar dalam CBSA. Jakarta. Rineka Cipta.

Sudjana, N. 2005. Penilaian Hasil Proses Belajar Mengajar. Bandung. PT Remaja Rosdakarya.

Trianto, 2007. Model-model Pembelajaran Inovatif Berorientasi Kontruktivistik. Jakarta. Prestasi Pustaka Undang-Undang Republik Indonesia Nomor 20 Tahun 2003 Tentang Sistem Pendidikan Nasional Beserta Penjelasannya. Jakarta. Cemerlang

Winataputra, Udin S. 2007. Teori Belajar dan Pembelajaran. Jakarta. Universitas Terbuka.

Winkel, W. S. 1996. Psikologi Pembelajaran. Jakarta. Gramedia.

Zaini, M. F. (2019). The Implementation Of Learning Management In Class VIII Madrasa Tsanawiyah Islamiyah (Mts) Ypi Batangkuis. International Conference on Islamic Educational Management (ICIEM). 